\title{
The Geopolitics of Decadence
}

\author{
REGENIA GAGNIER
}

Radical forgetfulness is but another form of radical hope.

Kobayashi Hideo, "An Approach to Les Fleurs du Mal" (Nov. 1927) ${ }^{1}$

A scheme of commercial competition tempered by the police-code, which we are pleased to give the name of a social order.

George Gissing, "The Hope of Pessimism" $(1882)^{2}$

$I^{\mathrm{T}}$ $T$ was a commonplace by the end of the nineteenth century that Britain and the United States were democracies within but empires without. As class, gender, race, ethnic, regional, and religious struggles advanced within the emergent democracies, international trade enabled by Victorian technological and financial innovations exploded on other continents and other peoples. Geopolitical ideologies of nationalism, liberalism, individualism, socialism, cosmopolitanism, social Darwinism, eugenics, and internationalism were borrowed or imposed through associations, movements, and phenomena such as liberal and conservative parties, the Communist International, trade unions, the New Imperialism and the "Pans" (Pan-Hellenism, Pan-Islamism, Pan-Asianism, Pan-Africanism), Zionism, May Fourth (China), the Meiji Restoration (Japan), the Tanzimat (Turkey), Theosophy, Esperanto, and the New Woman. The International Phonetic Alphabet and universal gold standard imposed Western metrics on global languages and currencies, and the global peasantry were incorporated into world economies. Most of the geopolitical partitions of our own contemporary global "hotspots"-India/Pakistan, Palestine/Israel, Ireland, Korea, Vietnam, Cyprus-were in territories subject to the wills of external superpowers or declining empires departing and transferring power to

Regenia Gagnier's monographs include Idylls of the Marketplace: Oscar Wilde and the Victorian Public (Stanford University Press, 1986); Subjectivities: A History of Self-Representation in Britain, 1832-1920 (Oxford University Press, 1991); The Insatiability of Human Wants: Economics and Aesthetics in Market Society (University of Chicago Press, 2000); Individualism, Decadence and Globalization: On the Relationship of Part to Whole, 1859-1920 (Palgrave, 2010); Literatures of Liberalization: Global Circulation and the Long Nineteenth Century (Palgrave, 2018). Gagnier holds the Established Chair in English Language and Literature at the University of Exeter and was president of the British Association for Victorian Studies (2009-2012).

Victorian Literature and Culture, Vol. 49, No. 4, pp. 607-620.

(C) The Author(s), 2021. Published by Cambridge University Press. This is an Open Access article, distributed under the terms of the Creative Commons Attribution licence (https://creativecommons. $\mathrm{org} /$ licenses/by/4.0/), which permits unrestricted re-use, distribution, and reproduction in any medium, provided the original work is properly cited.

doi:10.1017/S1060150320000236 
native elites. The late Victorian period was a time of extreme global disruption, like our own and with some of our own characteristics. "Global Literatures of Decadence," chapter 6 of my 2018 book Literatures of Liberalization: Global Circulation and the Long Nineteenth Century, treats the global circulation of a literary movement, decadence, and the rise of global decadent literatures under similar conditions of modernization. ${ }^{3}$ My aim there was to broaden the meaning of decadence in wider literary circulation, to begin to consider global literatures of decadence. Rather than appear as the last, effete gasp of declining civilizations, decadent literatures often appear in societies in which local traditions are in contact, and often in conflict, with the forces of modernization, less products of a modern European and North American movement than effects in most cultures undergoing similar processes of change. Offering a survey of diverse literatures from the late nineteenth to the twenty-first centuries, the chapter demonstrates that the factors contributing to the rise of the decadent movement in France and England-the decline of economic, social, religious, political, ethnic, regional, and gendered traditions under the forces of modernization that disrupted numerous relations of part to whole-have had similar effects elsewhere, giving rise to similar literary strategies. ${ }^{4}$ The chapter concludes with extended readings of two recent decadent works, Su Tong's Rice (1992), in which the geopolitical commodity is decadent fetish, and Michel Houellebecq's Soumission/Submission (2015), on the Islamization of France.

"Global Literatures of Decadence" focuses on the style and characteristics of the literature: the decline away from established norms, intense self-consciousness, restless curiosity in research, oversubtilizing refinement, and spiritual and moral perversity noted in 1893 by Arthur Symons; the acquiescence to suffering, stigma, and anxiety; the social alienation. This essay will focus on the geopolitical sources of global literary decadence. In the introduction to a major reassessment collected by the historian Michael Saler, The Fin-de-Siècle World (2015), Saler writes about the three waves of study of this particular period of modernization: the first was focused on Europe and North America, the second on the critical self-consciousness of the period, and the most recent on global exchanges. ${ }^{5}$ The conditions of rapid change and modernization that swept the world from the second half of the nineteenth century enforced the new nationalisms, imperialisms, racisms, anti-Semitisms, and, more positively, sexualities that are again sweeping the world today. The longue durée of modern globalization that began with British industrialization 
continues with our contemporary forms of technological expansion, international competition, populist disaffection, and accompanying forms of stress, anxiety, depression, nostalgia, regression: decadence. Concentrating on the geopolitical and economic conditions of the period and the cosmopolitanism and progressivism that resisted and continue to resist them, I conclude with a classic Japanese analysis of the condition, Kobayashi Hideo's "Literature of the Lost Home" (1933).

\section{EMPIRES AND RESISTANCES}

Modern decadence arose with empire and nation-states. Central Europe had four massive and multiethnic empires: the German, AustroHungarian, Russian, and Ottoman. Writing only of European decadent fiction from 1884 to 1927, George C. Schoolfield argued that decadents made their own artificial paradises while waiting for the end of national cultures in mongrelization or annihilation. ${ }^{6}$ German Oswald Spengler's Decline of the West $(1918,1922)$ theorized protofascism, with the nation as a mystical organic unity bound to a racial hierarchy of blood and soil, reacting against new, impersonal economies and finance, rootless intellectualism, and the excess cerebration of "elites." Russian Valery Briusov characterized the clash of empires in "The Last Martyrs" (1906), with extreme danger to those involved, as "an era of new life, which will unify our entire epoch into a single whole with the Russo-Japanese War and Charlemagne's campaigns against the Saxons. But we, all of us who are caught between two worlds, will be ground into dust on those gigantic millstones." ${ }^{7}$ The global, industrial crisis called the Great Depression of 1873-96 led to populist discontent (sound familiar?) that then led world leaders to the so-called Scramble for Africa, as European powers competed for markets, resources, and labor. In 1884 Bismarck convened the Berlin conference of newly unified European states to distribute Africa between French, British, German, Italian, Portuguese, Belgian, and Spanish interests. A groundswell of transnational white solidarity achieved global legal representation with race-based immigration policy. Lauded by Prime Minister William Gladstone and President Theodore Roosevelt, and invoked at the first meeting of the Australian Commonwealth Parliament, Australian MP Charles Henry Pearson's National Life and Characters: A Forecast (1893) championed legal protection of temperate zones where white men settled against incursion from "black" and "yellow" races, ${ }^{8}$ providing a forecast of our own alt-right fears of "white genocide," "the Great 
Replacement [of whites by people of color]," and "Invaders." The comparison holds today, with the alt-right's perception that "conservatives obsess over [neoliberal economic policy], small bourgeois concerns, but they fear tackling demographic questions [of race], which the Alt-right consider existential" and with their perception of their shared membership in a white anglophone diaspora that gives common cause. ${ }^{9}$

One should not understate the growth of humanitarianism and the discourse of universal human rights that flourished during the later nineteenth century. Among progressives both then and now, a discourse of human rights opposed both racist and classist divisions. These included not only the Communist International but also global cosmopolitan and antiracist movements such as Theosophy; journals with global circulation like Anti-Caste, Fraternity, African Times and Orient Review, and Zamindar; newspapers like Pan African; and organizations such as the League Against Imperialism, the International African Service Bureau, Movement for Colonial Freedom, and the Pan African Association and Conference of July 1900 that saw London as both a crossroads of empire and site of antiracist and anticolonial ferment. ${ }^{10}$ Nonetheless, the new nationalisms and new imperialisms of the final quarter of the nineteenth century were consolidated through their constructed Others and aided by "scientific" racial ideologies, social Darwinism, and eugenics. The abolition of the slave trade coincided with deepening racial stratification until the "scientific" racism of the Fin (today rebranded as "race realism"). ${ }^{11}$ Yet like capitalism and the commodity form, race is not a thing but a relationship between people.

Victorianists know well about the Boer Wars of the 1880s to 1902 in South Africa. The scramble for Africa by European powers entailed a massive destruction of the continent's cultures. ${ }^{12}$ The Kingdom of Benin was plundered for the artworks that inspired Picasso, Matisse, Gauguin, Derain, and Klee; Central Africa usurped by the Congo Free State was plundered for ivory and rubber, and Zulu South Africa for diamonds. Other kingdoms encroached upon by Europeans included the Asante federation; Tukolor, Sokoto, and Kongo Empires; Yorubaland; and the Kingdoms of Ijebu and Dahomey ${ }^{13}$ Reflection on the African diaspora inspired Cuban Fernando Ortiz's theory of transculturation in his Los negros brujos / Negro Sorcerer (1906) and Los negros esclavos / The Negro Slaves (1916), his Glosario de Afronegrismos (1924), and his antifascist El engaño de la raza / Deception of Racialism (1947).

After the war with Japan that Briusov saw as epitomizing the violence of modern nation-states, Russia was struggling with the 1905 and 1917 
revolutions. The Roman Empire had long since decayed, and Italy was registering the failures of the modern Risorgimento, including cynicism about corrupt elites, an underambitious populace, failures of parliament, banking scandals, and defeat in Ethiopia. After sequential rebellions in Argentina, Mexico, Peru, Venezuela, and Paraguay, culminating in the Cuban Revolution of 1898, Spain was indecisive between its roles in Europe and Latin America, with slow industrialization on the peninsula and 50 percent of its population illiterate. Post-Napoleonic France was "politically divided, militarily disgraced, territorially dismembered, economically lackluster, demographically stagnant, religiously lapsed, psychologically unanchored, socially unstable, sexually deviant, and artistically fragmented," ${ }^{14}$ giving rise to antimodern ressentiment and resistance, as is well known from the textbook ("breviary" in the period's term) decadence of Joris-Karl Huysmans.

Also well known among Victorianists is the North Indian "Mutiny" of 1857, better known in India as the First War of Independence. Less well known is that its epicenter, Lucknow, capital of the Kingdom of Awadh, was also the center of Urdu rekhti poetry, authored by men but with women speakers and about women's pleasure. The East India Company associated it and the kingdom with women, musicians, poets, eunuchs, impotence, and homosexuality in order to declare its highly cultured rulers illegitimate. Britain (or the EIC, a transport company functioning as a colonizing state, the high-tech firm of the British Empire, and avatar of our own multinationals) usurped the kingdom in 1856, catalyzing the rebellion. Taking up the ideology of the Raj, Hindu litterateurs themselves eventually dubbed eighteenth-century riti poetry "Decadent." 15

European imperialism and professional Orientalism arose together as territorial conquest required new knowledge. Friedrich Nietzsche's Thus Spake Zarathustra (1883) criticized European decadence and Christian docility through the voice of a pre-Islamic Persian prophet's auto-emancipatory will combined with Nietzsche's idiosyncratic version of social Darwinist will to power. Struggling both with modernization and with Western labels of decadence, the Arabic Nahda, or Renaissance, resisted the romantic Orientalism and sex tourism of francophone Flauberts and anglophone Burtons. The European construction of a unified and identifiable "Islamic civilization" played a role in hegemonic Europe's idea of itself and transformed how diverse Muslims saw themselves and their history. ${ }^{16}$ The Nahda's emphasis on reform and rationalism declined with the rise of Pan-Islamism, now 
attempting to reintegrate a fragmented modern umma (global Muslim community), just as the idea of "despot" had to be learned among the Ottomans in response to self-serving western representations. ${ }^{17}$ Fin de siècle revolutions spread through the Middle East from the 1880s to Iran in 1906, as British, Belgian, and Russian capitalist companies bought up and distributed among themselves key sectors in agriculture, industry, and infrastructure. Pan-Hellenism against the Ottomans; Pan-Africanism, Pan-Asianism, and Pan-Islamism against the Europeans; and Zionism all rose during this period. ${ }^{18}$ A history of anti-Semitism in Europe morphed, through the management of the British, into a history of settler colonialism in Palestine. ${ }^{19}$

This introduces the study of comparative empires or interimperialities, for Britain was by no means the only empire during the late nineteenth century. Watching the "unequal treaties" imposed by Western powers on Chinese ports beginning with Nanking in 1842, Japan defeated the Qing in 1895, which was followed by the Manchu Dynasty's unsuccessful self-strengthening and New Policy movements. The Qing was finally toppled in 1912 and the republic founded under Sun Yat-sen, with the rise of the New Culture and May Fourth liberal, modernizing movements. In 1853 the American commodore Matthew C. Perry arrived to "open" Japan, the 250-year-old Tokugawa Shogunate dissolved under the young Emperor Meiji's (1868-1912) modernization reign, the Shogun capital Edo became Tokyo, and the Sino-Japanese War of 1895 and Russo-Japanese War of 1905 followed. While the Meiji imposed an ethos of individualism, self-help, selfreliance, competition, and resilience in the service of the empire, such cosmopolitical shows of strength were challenged internally by over 3,000 peasant uprisings; bankruptcy of 108,050 farm households; and 400,000 agricultural people without means of livelihood. ${ }^{20}$ Elsewhere in Asia, the New Imperialism reshaped Burma (now Myanmar), Afghanistan, British Ceylon (now Sri Lanka), and French Indochina. By the early twentieth century, Pan-Asianists (usually including Japan, China, and India) were rejecting everything from university curricula to Theosophy as Western forms of domination. ${ }^{21}$

The Meirokusha modernizers of the Meiji Restoration criticized Western inequality, disrespect of parents, "primitive" religious belief in a personal God, mistreatment of colonized peoples and especially of Native Americans, obsession with money-making and materialist values, and lack of sophistication about other cultures. Yet, as social Darwinism and the theory of evolution took over from liberalism, the Meiji state 
became the highest level for organic unity; "just as single-cell organs develop into multicell organisms, individuals develop into States," and states would be in conflict. ${ }^{22}$ During times of rapid change and stress, nationalism tends to come to the fore.

Yet, as we've said, there were always forms of progressive critique and resistance. As the guest editor of this special issue on "decadence" has a special interest in New Age and ecocriticism, we might note that most of their manifestations go back to late nineteenth-century organizations like the Kyrle Society, the Society for Protection of Ancient Buildings, the Manchester Noxious Vapours Association, and the aforementioned Theosophical Society. The latter was founded in 1875 with the explicit mission (as finalized in 1896):

1. To form the nucleus of a universal brotherhood of humanity, without distinction of race, creed, sex, caste, or colour.

2. The study of ancient and modern religions, philosophies and sciences, and the demonstration of the importance of such study.

3. The investigation of the unexplained laws of nature and the psychical powers latent in man. ${ }^{23}$

The Buddha was born in what is now Nepal, and Buddhism had died out in South Asia by the thirteenth century. It was reconstructed by European Orientalists, and by the end of the nineteenth century, Weltreligionen, or world religions, included reinvented Buddhism with reinvented Christianity (e.g., the Higher Criticism), and with reinvented Hinduism, Islam, and Judaism. ${ }^{24}$ Writing from industrialized western Europe, Marx had thought that economic well-being and religious belief were inversely proportional, that as standards of living rose people would need the "opiate" of religion less. With less idea- or belief-based religions and more practice-based spiritualities like Buddhism, and with the return in the twenty-first century to religious fundamentalisms in both Christianity and Islam, the jury is still out. What is clear is that not only the late-Victorian syncretisms of Theosophy and other global movements but also the world religions themselves were undergoing transformations and modernizations in the service of nation-states and empires.

The distinguished Japanese specialist John Rosenfield has untangled an especially illuminating case of spiritual transculturation cum Bengali, Irish, U.S., and Japanese nationalisms from Swami Ramakrishna's (1836-1886) and Swami Vivekānanda's (1863-1902) A'dvaita ideal (the underlying harmony of the five world religions and the unity of 
humankind) via the Irish educator Margaret Nobel (Sister Nivedita, 1867-1911), through American philanthropist/patrons Josephine MacLeod (1858-1949) in New York City and Sara Bull (1850-1911) in Boston, through Japanese connoisseurs and educators Okakura Kakuzō (1863-1913) and Ernest Fenollosa (1853-1908). ${ }^{25}$ Okakura pronounced that "Asia is one. The Himalayas divide, only to accentuate, two mighty civilizations, Chinese with its communism of Confucius, India with its individualism of the Vedas." He further proposed that "Arab chivalry, Persian poetry, Chinese ethics, and Indian thought, all speak of an ancient Asiatic peace, in which there grew up a common life." "If Asia be one... the Asiatic races form a single mighty web" (64).

In terms of critique, the United States was seen as a "Caliban" by its neighbors to the south for its racism, popular sovereignty, and workaholism in its rise to international power and expansionist policies over Latin America and the Philippines. ${ }^{26}$ As early as 1848 , when workers throughout Europe were rebelling in class warfare, the United States was annexing half of Mexico, and only the less populated half because, in the words of U.S. Senator John C. Calhoun, incorporating too many people of color would be "fatal to our institutions." ${ }^{27}$ Struggling between, on one hand, a colonial and an economic empire, Spain and the United States, and, on the other, a Britain intent on extraction of the continent's bountiful natural resources, Latin Americans saw massive migration to cities, urbanization, and the rise of popular cultures and multicultural street languages as seen in the modernistas. Cuban writer and patriot José Martí remarked on the dizzying acceleration in communication, transport, and logistics and on how continuing colonization and exploitation prevented any real divorce between literature and politics, leading to South America's own forms of decadence: "All is expansion, communication, florescence, contagion, diffusion... There is not enough time to give form to thought. Ideas are lost in each other in the sea of our minds. . . And hence the shimmering works of our time, and the absence of those great culminating works. ${ }^{28}$

One scholar of Japanese culture, Eric Hayot, has described in similar terms the relation of world, a homespace or lifeworld that we inhabit, to globalization, a process or transformation that often acts upon us, like Marx's description of capitalism as a juggernaut, or when an Asian crop (sugar) is introduced around 1780 to Latin American producers and worked by African slaves for the consumption of Europeans and North Americans. ${ }^{29}$ The transformations of globalization, writes Hayot, "are paradoxes: more communication, less community; more difference, 
less diversity; more speed, less time." ${ }^{30}$ We see this stress around speed and movement in all the decadent literatures of the fin de siècle. Briusov's The Fiery Angel (1907) is set in medieval Germany, works through the Spanish Inquisition, and ends in the New World of Spanish America. Norwegian Knut Hamsun's Hunger/Sult (1890), translated by the British "New Woman" George Egerton (1899), begins in Christiania, Norway's capital (today Oslo- "It was during the time I wandered about and starved in Christiania"), and ends with the starving, homeless protagonist catching a boat for Cadiz ("and bade farewell for the present to. . Christiania, where the windows gleamed so brightly in all the homes"), the last word for the homeless being the homes from which they are excluded. ${ }^{31}$ In the Soviet writer Mikhail Bulgakov's The Master and Margarita (1938), everything is madness in Moscow: suits that write by themselves (the rise of bureaucracy), commissioners who burst into synchronized song, foreign currency and crucifixion everywhere.

It is clear from the above that globalization, nationalism, conflict, and inequality - as well as the progressive, critical movements resisting them at the fin de siècle-were not entirely alien to today's own multinationals, nationalisms, racisms, populisms, or the movements resisting them. Holbrook Jackson emphasized the positive response to this tension or anxiety about change when he described the 1890s, the peak of decadence in Britain, as "A decade singularly rich in ideas, personal genius and social will," whose "central characteristic was a widespread concern for the correct-the most effective, most powerful, most righteousmode of living." 32 Patrick Brantlinger's Rule of Darkness (1988) and Dark Vanishings (2003) and Nathan Hensley's Forms of Empire: The Poetics of Victorian Sovereignty (2017) have shown the bloodiness of the period, and Priyamvada Gopal's Insurgent Empire: Anticolonial Resistance and British Dissent (2019) has shown the extent of resistance to British imperial rule. My book Individualism, Decadence and Globalization: On the Relationship of Part to Whole (2010) focuses on the creative progressives at the fin, from the socialists and feminists, cultural philanthropists, spiritualists and mystics, cosmopolitans, and gypsy lorists to the vegetarians and antivivisectionists, who not only defended the oppressed but also provided countless models of better societies with better international and interspecies relations. ${ }^{33}$ The fin de siècle was a period of tremendous change, disorientation, and brutality but also tremendous hope and faith in humanitarian and extrahumanitarian capabilities. The languages of populism-of us versus them, the people versus an elite, of racial and national difference-have been and continue to be opposed by 
progressive and revolutionary forces. Decadent literatures and art forms have registered, and will continue to register, extreme times like these.

\section{The Lost Homes of Modernity}

I conclude with an earlier reflection on decadence composed in 1933. Writing at the height of Japanese nativism, or "the return to Japan," Kobayashi Hideo, considered by many to be the greatest modern critic in Japan, reflects on the alienation that takes recourse in nostalgia and nationalism. His "Literature of the Lost Home" begins, "In our day it is not at all strange that a writer's passion would assume a certain peevish, perverse expression." 34 Born in Tokyo, he "cannot fathom what that really means. Mine is an unsettled feeling that I have no home" (48). Unlike his peers who in their social alienation have turned in a spirit of rigid binary contradiction toward nature, Kobayashi's reflective intelligence rejects consoling antitheses:

\footnotetext{
It is not at all a matter as straightforward and reasonable and innocent as "loving nature." I have grown increasingly sceptical about the existence of anything concrete and actual behind my being moved by the beauty of Nature. Looking closer, I see much in common between intoxication by the beauty of a mountain, and intoxication by the beauty of an abstract idea. I feel as though I am looking upon two aspects of a spirit that has lost its home. Consequently, I am not heartened by the recent craze for mountain climbing. And I feel all the more uneasy as the number of afflicted climbers rises each year. . . I do not easily recognize within myself or in the world around me people whose feet are planted firmly on the ground, or who have the features of social beings. I can more easily recognize the face of that abstraction called the "city person," who might have been born anywhere, than a Tokyoite born in the city of Tokyo. (49-50)
}

The other side of cosmopolitanism or world-citizenship can be found in Prime Minister Theresa May's negative declaration, in a moment of British populist theater, "if you believe you're a citizen of the world, you're a citizen of nowhere" (Tory Party conference, October 5, 2016). For Kobayashi, this "city person" "may produce a certain type of literature, although it will be deficient in real substance. The spirit in exhaustion takes flight from society and is moved by the curiously abstract longing to commingle with Nature.... [Y] et there is no reason to believe that any real writing will come of it" (50).

Drawing on the struggles of one of the then world-hegemons, Russia, Kobayashi then explains westernization via Dostoevsky. His Raw 
Youth (1875), Kobayashi tells us, "is no stranger [to the Japanese]-a youth whose mind is in turmoil because of Western ideas and who, in the midst of this intellectual agitation, has utterly lost his home" (50). He records the emergent social need for violent sensation at worst and for intense feeling at best as illustrated in literature and the arts: "Some suggest that in a period of social collapse, when no definite or stabilizing ideas are in force, people have a renewed desire for sensual stimulation or excitement.. . I believe that the hearts of the masses are captured almost involuntarily... [by] the capacity of a film to make them unconsciously surrender to a stream of real emotions" (52). Kobayashi concludes that "we are young people who have lost our youthful innocence. Yet we have something to redeem our loss. We have finally become able, without prejudice or distortion, to understand what is at the core of Western writing. . . . History seems always and inexorably to destroy tradition. And individuals, as they mature, seem always and inexorably to move toward its true discovery" (54). Dostoevsky, Briusov, Bulgakov (Russia), Hamsun (Norway), Martí (Cuba), Kobayashi (Japan) - all share the language of the lost homes of modernity and modernization. Back in London, George Gissing was writing "The Hope of Pessimism" (1882) and Born in Exile (1892).

Kobayashi thought that "Japanese society [was] collapsing in a quite distinctive way" (53). Yet modern literatures since the nineteenth century indicate some broad patterns. The major resistances to the effects of capitalist globalization over the last 150 years were international socialism and social democracies as welfare states. In addition to those above, we could trace transcultural political movements from Ho Chi Minh and Chiang Kai-shek through Paris, with Ho among the founders of the French Communist Party. The Bengali intellectual and activist M. N. Roy was among the founders of the Mexican Communist Party. Our current global struggles are no longer between capitalism and socialism, or between free-market individualism and social planning. For the moment, when the welfare state has been eroded and forms of social support are in decline, our choices appear to be between degrees of government. Will governments provide any degree of support or safety net for the less advantaged and vulnerable, the migrant, the unemployed, the homeless? Will governments provide education or health care for the young and the infirm, or will they leave individual citizens only local improvisations, so that if your background is privileged you may survive and, if not, not? Will governments provide any degree of environmental protection for future generations of diverse sentient species, or will they 
exploit global resources for short-term profits? Despite two centuries of progressive humanitarianism and environmentalism, we still seem very close to some of the more fundamental questions of late Victorian political economy and the decadent literatures that arose with it.

\section{NOTES}

1. Kobayashi, Literature of the Lost Home, 102.

2. Gissing, "Hope," in Essays, 90.

3. Gagnier, Literatures of Liberalization, 131-66. The book chapter is an extended version of my essay "Global Literatures of Decadence" in Michael Saler's The Fin-de-Siècle World.

4. For the famous European definition of decadence as a decomposition or deformation of the relationship between the part and the whole, see Gagnier, Literatures of Liberalization, 134-35.

5. Saler, The Fin-de-Siècle World.

6. Schoolfield, A Baedeker of Decadence.

7. In Lodge, The Dedalus Book of Russian Decadence, 23.

8. Auerbach, "The New Imperialism," in Saler, The Fin-de-Siècle World, 346.

9. Hawley, The Alt-Right.

10. See Tabili, "Race and Ethnicity," in Saler, The Fin-de-Siècle World, 518-34; and Gopal, Insurgent Empire.

11. See Saini, Superior.

12. See Brantlinger, Rule of Darkness and Dark Vanishings.

13. See Saunders, "Africa," in Saler, The Fin-de-Siècle World, 300-320.

14. Micale, "France," in Saler, The Fin-de-Siècle World, 113.

15. Vanita, "India," in Saler, The Fin-de-Siècle World, 283-99.

16. See Hourani, Arabic Thought.

17. Elshakry, "Islam," in Saler, The Fin-de-Siècle World, 582-98; Turnaoğlu, "Despotism (İstibdad) in Ottoman Political Thought."

18. See also Hanssen, "The Middle East," in Saler, The Fin-de-Siècle World, 266-82.

19. See Stanislawski, Zionism; and Cleary, Literature, Partition and the Nation-State.

20. Esenbel, "Japan," in Saler, The Fin-de-Siècle World, 258.

21. See Saaler et al., Pan-Asianism.

22. Hane, "Early Meiji Liberalism," 364. 
23. Cited in Lachman, "New Age Fin de Siècle," in Saler, The Fin-de-Siècle World, 614.

24. Lopez, "Buddhism," in Saler, The Fin-de-Siècle World, 599-610.

25. Rosenfield, "Beyond Tenshin."

26. Smith, "The United States," in Saler, The Fin-de-Siècle World, 199. This is of course in contrast to the revolutionary appropriation of Caliban as anticolonial rebel in, e.g., French writer Octave Mannoni, Martinican Aimé Césaire, Barbadian George Lamming, and Cuban Roberto Fernández Retamar in the twentieth century.

27. See Grandin, The End of the Myth.

28. Cited in Franco, "Latin America," in Saler, The Fin-de-Siècle World, 234.

29. Marx, Das Kapital. See also Belich, Replenishing the Earth, loc. 566.

30. Hayot, "World Literature and Globalization," 227.

31. Hamsun, Hunger, 3, 266.

32. Jackson, The Eighteen-Nineties, 12, 17.

33. See also Gandhi, Affective Communities.

34. Kobayashi, Literature of the Lost Home, 47.

\section{Works CITED}

Belich, James. Replenishing the Earth: The Settler Revolution and the Rise of the Anglo-World, 1783-1939. Oxford: Oxford University Press, 2009.

Brantlinger, Patrick. Dark Vanishings: Discourse on the Extinction of Primitive Races, 1800-1930. Ithaca: Cornell University Press, 2003.

- Rule of Darkness: British Literature and Imperialism, 1830-1914. Ithaca: Cornell University Press, 1988.

Bulgakov, Mikhail. The Master and Margarita. 1938. Translated by Michael Glenny. London: Harvill, 1967.

Cleary, Joe. Literature, Partition and the Nation-State: Culture and Conflict in Ireland, Israel and Palestine. Cambridge: Cambridge University Press, 2002.

Gagnier, Regenia. Individualism, Decadence, and Globalization: On the Relationship of Part to Whole. Basingstoke: Palgrave Macmillan, 2010.

- Literatures of Liberalization: Global Circulation and the Long Nineteenth Century. Basingstoke: Palgrave Macmillan, 2018.

Gandhi, Leela. Affective Communities: Anticolonial Thought, Fin-de-Siècle Radicalism, and the Politics of Friendship. Durham: Duke University Press, 2006.

Gissing, George. George Gissing: Essays and Fiction. Baltimore: Johns Hopkins University Press, 1970.

Gopal, Priyamvada. Insurgent Empire: Anticolonial Resistance and British Dissent. London: Verso, 2019.

Grandin, Greg. The End of the Myth: From the Frontier to the Border Wall in the Mind of America. New York: Metropolitan, 2019. 
Hamsun, Knut. Hunger/Sult. 1890. New York: Knopf, 1920.

Hane, Mikiso. "Early Meiji Liberalism: An Assessment." Monumenta Nipponica 24, no. 4 (1969): 353-71.

Hawley, George. The Alt-Right (What Everyone Needs to Know). Oxford: Oxford University Press, 2019.

Hayot, Eric. "World Literature and Globalization." In Routledge Companion to World Literature, edited by Theo D'haen, David Damrosch, and Djelal Kadir, 223-31. Oxford: Routledge, 2012.

Hensley, Nathan. Forms of Empire: The Poetics of Victorian Sovereignty. Oxford: Oxford University Press, 2017.

Hourani, Albert. Arabic Thought in the Liberal Age, 1798-1939. 1962. Cambridge: Cambridge University Press, 1983.

Jackson, Holbrook. The Eighteen-Nineties. New York: Mitchell Kennerley, 1913.

Kobayashi, Hideo. Literature of the Lost Home: Literary Criticism, 1924-1939. Edited by Paul Anderer. Stanford: Stanford University Press, 1995.

Lodge, Kirsten, ed. The Dedalus Book of Russian Decadence: Perversity, Despair and Collapse. Sawtry: Dedalus, 2007.

Marx, Karl. Das Kapital: Kritik der politischen Ökonomie. Vol. 1, 1867. www.marxists. org/archive/marx/works/1867-c1/ch25.htm.

Rosenfield, John. "Beyond Tenshin: Okakura Kakuzo's Multiple Legacies: Okakura Kakuzō and Margaret Noble (Sister Nivedita): A Brief Episode." Review of Japanese Culture and Society 24 (2012): 58-69.

Saaler, Sven, and J. Victor Koschmann, eds. Pan-Asianism in Modern Japanese History: Colonialism, Regionalism and Borders. New York: Routledge, 2007.

—, and C. W. A. Szpilman, eds. Pan-Asianism: A Documentary History. Lanham: Rowman \& Littlefield, 2011.

Saini, Angela. Superior: The Return of Race Science. London: Fourth Estate, 2019.

Saler, Michael, ed. The Fin-de-Siècle World. London: Routledge, 2015.

Schoolfield, George C. A Baedeker of Decadence: Charting a Literary Fashion, 1884-1927. New Haven: Yale University Press, 2003.

Stanislawski, Michael. Zionism: A Very Short Introduction. Oxford: Oxford University Press, 2017.

Turnaoğlu, Banu. "Despotism (İstibdad) in Ottoman Political Thought." History of Political Thought 41, no. 1 (2020): 16-42. 